\title{
ENSINO DE LEITURA E INTERPRETAÇÃO TEXTUAL A PARTIR DO TEXTO "UMA VELA PARA DARIO"
}

\author{
SILVA, Sílvio Ribeiro da - Doutorando em Lingüística Aplicada/UNICAMP - \\ Docente CAJ/UFG - ssilva2@uol.com.br
}

RESUMO: As atividades de leitura e interpretação de textos desenvolvidas em sala de aula seguem uma perspectiva decodificadora. Aos alunos são propostas questões cujas respostas são de fácil identificação no texto, não oferecendo desafios. A partir disso, este artigo apresenta a prática de ensino de dois professores de uma escola pública a partir de atividades de leitura e interpretação, elaboradas por eles, do texto Uma Vela para Dario. Observamos se os professores partiram de uma prática decodificadora de leitura, ou se apresentaram uma visão de leitura como um processo no qual deve ser construído um sentido.

Palavras-chave: Leitura; Interpretação de Textos; Construção do Sentido

\begin{abstract}
The reading and interpretation activities developed in classroom follow a decodificating approach. Teachers have their students answer questions whose answers are too easily identifiable in the text, not offering them any challenge. This article presents the teaching practice of two teachers from a public school based on reading and interpretation activities they elaborated on the text Uma Vela para Dario. I observed if the teachers either based themselves on a decodificating approach of reading, guided by a conception which sees the text as a heap of information and the reader as the mere responsible for the decodification of the linguistic signs, or if they presented a view of reading as a process in which meaning must be built up.
\end{abstract}

Keywords: Reading, Text Interpretation, Construction of Meaning

\section{Introdução}

No ensino de Língua Portuguesa, devem ser oportunizadas aos alunos atividades nas quais eles possam desenvolver práticas de leitura e perceber o papel interativo que desempenham com o texto. Saber Língua Portuguesa não é saber sua estrutura ou o seu funcionamento apenas, nem é saber analisá-la gramaticalmente. Saber a língua significa saber se movimentar dentro dela. Segundo Carvalho (1997), a língua é como uma armadura dentro da qual nos movimentamos no dia-a-dia da interação humana. $\mathrm{O}$ uso adequado da língua nos permite o exercício amplo e correto da cidadania. Para Mac \& Welti (1995), saber uma língua é ter conhecimento completo de como dizer, a quem dizer, quando e onde dizer. 
Quando a escola não ensina o aluno a usar a língua de forma adequada, ela falha muito, porque acaba formando autômatos ao invés de pessoas capazes de se movimentar dentro do sistema lingüístico no qual estão vivendo.

Uma das formas de se fazer com que o aluno seja capaz de se manifestar dentro do sistema é através da leitura. Segundo Moita Lopes (1996), a leitura é um modo específico de interação entre participantes discursivos, envolvidos na construção social do significado: a leitura é uma prática social. Sendo uma prática social, é a leitura que vai permitir ao aluno a interação com os outros, participando e discutindo todos os acontecimentos que estão a sua volta.

O professor deveria direcionar a atividade de leitura no sentido de ser ela uma das responsáveis pela interação do aluno com o mundo. A leitura deveria ser vista sob o aspecto social, não se esquecendo de que a ela é também peça fundamental para que um aluno aprenda a escrever.

Ler e escrever são atividades que se completam. Os bons leitores têm grandes chances de escrever bem, já que a leitura fornece matéria-prima para a escrita. Quem lê mais tem um vocabulário mais rico e compreende melhor a estrutura gramatical e as normas ortográficas da língua.

A leitura deve ser entendida como atividade de vital importância em uma aula de Língua Portuguesa e de qualquer outra área. Saber ler é tão importante que tal ato ajuda muito o aluno a entender outras áreas com as quais convive na escola.

Para Freire (1986), a escola desconhece que o ato de ler precede a leitura da palavra. A escola não se lembra de que o aluno já sabe fazer diversas leituras quando chega até ela. Ela se esquece de que o aluno chega com muitos conhecimentos, mas ele não sabe utilizá-los.

Levando em conta essas questões sobre leitura, apresentamos neste artigo a experiência de atividades de leitura e interpretação de textos desenvolvidas por dois professores formados em Letras pelo Campus Avançado da Universidade Federal de Goiás em Jataí. Nosso interesse era detectar qual concepção de leitura era predominante na abordagem que fariam para a leitura e a interpretação do texto sugerido por nós. Para a coleta dos dados, gravamos em vídeo duas aulas geminadas de cada um dos professores. Cada aula teve duração de 50 minutos. 
Revista Eletrônica de Educação do Curso de Pedagogia do Campus Avançado de Jataí da Universidade Federal de Goiás [Vol I - n.2 ] [jan/jul] [ 2006 ]

ISSN: $1807-9342$

Acreditamos que a experiência oportuniza a avaliação não só da prática de ensino dos dois, mas, de certa forma, da maneira como conduzimos os alunos em sua formação no curso de Letras. 
Ltinerarius

eflectionis
Revista Eletrônica de Educação do Curso de Pedagogia do Campus Avançado de Jataí da Universidade Federal de Goiás [Vol I - n.2 ] [jan/jul] [ 2006 ]

ISSN: $1807-9342$

\section{A Leitura e o Ato de Ler Escolar}

O trabalho com atividades de leitura envolve várias etapas. Ler um texto é uma atividade que consiste em compreendê-lo, interpretá-lo, não apenas decodificar seus sinais. O conhecimento anterior e as experiências passadas funcionam como base para a compreensão da leitura. Isto porque muito antes de as crianças dominarem o ato da leitura elas já têm experiências com o mundo e com a língua.

O dever da escola então é fazer com que o aluno aprenda o que não sabe. Ler o mundo ele já sabe. O que precisa aprender é a ler a palavra, mas não a palavra isolada. Segundo Bakhtin (1997), a palavra constitui o produto da interação do locutor e do ouvinte. Através da palavra, defino-me em relação ao outro, isto é, em última análise, em relação à coletividade. A escola deve então ensinar ao aluno a forma adequada de usar a palavra, uma vez que ela pode transformá-lo, dar uma nova dimensão à sua consciência, o que acaba por possibilitar-lhe uma reflexão sobre a sua realidade e a maneira de agir sobre ela.

Ler faz com que o aluno esteja presente no mundo social. A leitura é uma forma de interação mediada entre o que está escrito e os interlocutores que não se encontram face a face. A leitura pode ser uma fonte de informação, prazer, conhecimento. Ela dá acesso às informações necessárias para o dia-a-dia e aos mundos criados pela literatura, pelas ciências. O professor deve ser capaz de mostrar aos alunos que eles são agentes da leitura, são sujeitos ativos.

Mas o que acontece é que as atividades de leitura não são desenvolvidas na escola. E quando são costumam acontecer de uma forma inadequada.

O material que é entregue para que o professor trabalhe com os alunos é feito com base em uma concepção de linguagem que não privilegia a interação. Os textos costumam ser usados como pretexto para o ensino gramatical e treino ortográfico. Assim, parece que o que se quer é fazer com que o leitor se fixe ao sistema gramatical da língua, entendido como lugar da constituição formal do texto legítimo.

Também são encontradas nesse tipo de material perguntas conhecidas sobre a compreensão do texto lido, através das quais o leitor é levado a reconhecer, localizar ou selecionar informações para respondê-las.

As estratégias cognitivistas de leitura crucificam a leitura feita assim, tida apenas como decodificadora. Propõem modelos interacionais nos quais o autor e o leitor 
devem construir juntos o sentido do texto. Comparando tal atividade de interação com a linguagem falada, Kleiman (1995, p. 66) diz:

"O autor, que segura a palavra, por assim dizer, por um turno extenso, como num monólogo, deve ser informativo, claro e relevante. Ele deve deixar suficientes pistas em seu texto a fim de possibilitar ao leitor a reconstrução do caminho que ele percorreu. (...) Já o leitor deve acreditar que o autor tem algo relevante a dizer no texto, e que o dirá clara e coerentemente. Quando obscuridades e inconsistências aparecem, o leitor deverá tentar resolvê-los, apelando ao seu conhecimento prévio de mundo, lingüístico, textual, devido a essa convicção de que deve fazer parte da atividade de leitura de que o conjunto de palavras discretas forma um texto coerente, isto é, uma unidade que faz com que as partes se encaixem umas nas outras para fazer um todo".

Segundo afirma Kleiman, o leitor, da mesma forma que o autor, parece já ter constituído um sentido para aquilo que seria o texto. Assim, o texto deve ter pistas, deixadas pelo autor, que sejam suficientes para que o leitor reconstrua aquilo que se quis dizer.

Mas isso não é o suficiente para que um texto seja entendido e interpretado por um leitor. A posição de leitor, o movimento sobre o texto e o sentido atribuído àquilo que se lê está determinado antes de tudo por um processo histórico e pelas condições de produção. O texto é feito como possuindo um grande aparato social. Ele é feito através de uma grande quantidade de formações ideológicas, sociais e até mesmo imaginárias. Tais formações acabam por designar o lugar discursivo através do qual um sujeito acaba sendo levado a atribuir sentido a si mesmo e ao outro.

O texto precisa de legibilidade para que seja entendido. Segundo Kleiman (1996), a legibilidade de um texto, num sentido amplo, tem a ver com a estruturação do texto, tanto no desenvolvimento quanto na apresentação de relações, para permitir ao leitor seguir, avaliar.

O sujeito e os sentidos são atravessados pelas formações ideológicas, sociais e imaginárias. Tais formações determinam as possibilidades do dizer e, portanto, o sentido daquilo que seria um texto legível e daquilo que poderia ser dito sobre ele.

O processo cognitivo de leitura mostra que há uma relação direta entre o sujeito leitor e o texto enquanto objeto; também existe relação entre a linguagem escrita e a compreensão, entre a memória, inferência e pensamento. A interpretação acontece quando o leitor consegue decodificar os sinais gráficos e usar o conhecimento armazenado na memória sendo capaz então de interagir com o autor e elaborar outros textos a partir de um primeiro. 
Ltinerarius

Teflectionis

\section{Perspectivas de Leitura}

$\mathrm{Na}$ perspectiva decodificadora de leitura, o ato de ler se limita a uma decodificação do sistema lingüístico, da letra para a palavra, sentença e significado.

$\mathrm{O}$ ato de decodificar se constitui num processo muito diferente da leitura. Claro que o conhecimento da correspondência entre som e letra é necessário para a leitura. $\mathrm{O}$ leitor eficiente não decodifica, "ele percebe as palavras globalmente e adivinha muitas outras, guiado pelo seu conhecimento prévio e por suas hipóteses de leitura" (Kleiman, 1996, p. 68).

$\mathrm{Na}$ visão decodificadora, o leitor apenas procura o significado presente na letra, sílaba, palavra, texto; ele é passivo. O leitor lê letra por letra, palavra por palavra decodificando-as até que o significado seja formado em seu cérebro. Em uma aula em que predomina o trabalho com a leitura decodificadora, na maioria das vezes, o aluno nem sabe o que está lendo. É como se se interpretasse uma nota musical por si só.

Partindo para uma concepção psicolingüística, temos a relação leitor/texto. O leitor usa os seus pré-conhecimentos para entender o texto. Ao lê-lo, ele procura em sua cabeça imagens, visões, a fim de interpretar o que está lendo. Ele precisa de muitas informações visuais, caso contrário terá muita dificuldade para entender o que está lendo.

Segundo os seguidores desta concepção, a aprendizagem vem a ser o resultado de uma interação entre o ambiente e as estruturas cognitivas que o aprendiz já possui. O aprendiz é visto então, segundo Brággio (1992), não como um recipiente passivo de estímulos do ambiente, mas um processador da informação ativo e seletivo.

Na concepção interativa de leitura, temos o aluno que acessa esquemas que ele possui em sua cabeça. A leitura torna-se um ato perceptual e cognitivo. O fluxo da informação vai do leitor para o texto e vice-versa, simultaneamente. A atividade de leitura interativa é definida por Kleiman (1996) como sendo uma intenção à distância entre leitor e autor via texto.

O leitor interativo utiliza associações de diferentes tipos: experiências pessoais, sinônimos, antônimos, definições, atributos, inferências, pressuposições, conhecimento de mundo, experiências e crenças além das estratégias cognitivas requeridas.

Na concepção interativa de leitura o autor dá pistas ao leitor e este, através dos esquemas que possui, é capaz de criticar as visões, as pistas dadas; e é esse o bom leitor. O significado do texto é construído pelos vários outros significados criados pelos sujeitos envolvidos na interação. 
O texto então não traz todos os seus significados. É o leitor quem vai construí-los quando interage com ele. Segundo afirma Brággio (op.cit. p. 43),

"a leitura torna-se vista como um ato construtivo, onde todos os leitores elaboram sobre as idéias selecionadas de um texto, construindo um significado para ele. Portanto, a construção do significado é concebida como um produto da interação entre o leitor e o texto".

É importante ressaltar a presença do autor na atividade de interpretação de um texto por um leitor. Ao escrever, o autor acaba deixando transparecer seus próprios valores, conceitos, experiências e até mesmo os esquemas que possui. O texto acaba sendo influenciado pelas características específicas e pessoais de quem o escreveu de forma que isso virá a refletir o que o autor é e o que está tentando comunicar num dado momento sóciohistórico.

Acreditamos que deve haver uma espécie de contrato, de cumplicidade entre o autor e o leitor. Aquele cria situações de significado, estrutura, forma; este constrói o significado real no ato de interpretar feito durante a leitura.

\section{E o Professor? Onde Entra?}

O trabalho do professor em uma aula de leitura é ser um mediador entre o texto e o aluno. Ele não deve orientar as atividades de leitura de forma a fazer com que sejam oriundas do texto para o leitor, ou do leitor para o texto. Se assim fizer, transforma o ato de ler em uma atividade inócua e sem fundamento.

Os textos a usar na aula são naturalmente marcados ideologicamente e essas marcas ideológicas não terão que ser disfarçadas pelo professor, escondidas ou ignoradas em nome da imparcialidade utópica. O professor terá que assumir a presença delas e apresentá-las ao aluno, demonstrando o funcionamento ideológico dos vários tipos de discurso, sensibilizando o aluno à força ilocutória presente em cada texto, tornando-o consciente de que a linguagem é uma forma de atuar, de influenciar, de intervir no comportamento alheio, que os outros atuam sobre nós usando-a e que, igualmente, cada um de nós pode usá-la para atuar sobre os outros.

A atividade de leitura em sala de aula deve ser vista como um acontecimento em que haja um relacionamento entre o leitor e o texto. Esse acontecimento deve ocorrer sob circunstâncias específicas, num contexto social e cultural também específico 
como sendo uma parte da vida do indivíduo e do grupo a que o leitor pertence. A compreensão de um texto depende das corretas relações que há entre o leitor e o autor no momento em que a leitura do texto está sendo feita.

A atividade com a leitura deve, nas palavras de Brággio (op. cit. p. 69),

"ser vista dentro de uma matriz pessoal, social, histórica e cultural, pois não somente o que o leitor traz para a transação de sua experiência passada de vida e de linguagem, mas também as circunstâncias socialmente moldadas e propósito da leitura, dão a contextualização para o ato de simbolização".

O professor deve fazer com que a atividade de leitura transforme o aluno em um sujeito atuante, participativo, construtor do significado daquilo que lê. A prática da leitura em sala de aula costuma ser um pouco desvinculada daquilo a que a verdadeira atividade de leitura se refere, isto é, o ato de interação e participação social.

\section{As Aulas em Questão}

Cada um dos professores (aqui chamados de Murilo e Rodolfo) recebeu uma cópia do texto Uma Vela para Dario, de Dalton Trevisan. A escolha do texto foi feita por nós. Talvez isso tenha se constituído em uma atitude um pouco autoritária, mas foi a maneira encontrada para homogeneizar a pesquisa que seria desenvolvida.

\section{Aula do professor Murilo}

O professor Murilo começou a sua aula falando um pouco sobre o que o texto trataria. Perguntou aos alunos como eles agiriam em um situação em que vissem que uma pessoa agonizava para morrer. Houve algumas opiniões por parte dos alunos, mas pôde ser percebido que a fala deles era meio desmotivada, parece que falavam sem interesse.

Então ele pediu para que os alunos fizessem a leitura silenciosa do texto e sublinhassem as palavras desconhecidas para depois poderem procurar o significado contextualizado. Ele frisou bastante a questão da procura de palavras desconhecidas.

Depois de os alunos terem feito a leitura do texto, o professor começou a questioná-los sobre as palavras desconhecidas.

Murilo: a palavra rabecão apareceu na linha 34. Alguém sabe o que significa? 
A1: carro da funerária, do IML?

Murilo: isso! É um veículo que transporta cadáveres, particularmente pessoas indigentes, pessoas que morrem na rua, né, que não se sabe quem é. O que mais? (...) Mais alguns termos que eu quero discutir com vocês. Por exemplo, na linha 04 apareceu a seguinte palavra: "dois ou três passantes", qual o significado de passantes?

A2: pessoas que passavam.

Murilo: pessoas que passavam? E nessa frase aqui: "o fiscal do ônibus retirou os passageiros passantes", qual o significado?

A1: os passageiros que estavam pagando para passar na roleta.

Murilo: quer dizer, nesse caso aí, a palavra "passantes" seria quem está excedendo, tá? Agora vamos observar o quanto é importante no português, pra gente definir o sentido de uma palavra, devido à questão da palavra ter vários sentidos, então o contexto, a frase..., o contexto vai definir qual o sentido que ela possui. Então, no caso do texto, a palavra passantes aí seria a pessoa que passava pelo local. Bom, na linha número 12, temos aí: "as crianças foram despertadas e de pijama acudiram à janela", qual o sentido de acudiram aí?

A2: foram pra janela ver o tumulto.

Murilo: foram pra janela? E nessa frase aqui: "o rapaz foi acidentado, mas algumas pessoas o acudiram", o que significa?

A2: deram ajuda.

Murilo: perceberam então a mudança? O significado? Então, mais uma vez quero provar a importância do contexto. Na linha 15 aí, "a velhinha de cabeça grisalha...", qual o sentido de grisalha aí?

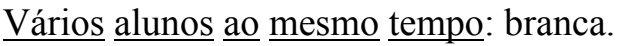

O objetivo do professor Murilo em trabalhar com o léxico foi bastante viável. Apenas podem ser pertinentes alguns comentários sobre a forma como ele quis desenvolver essa atividade.

Kleiman (op. cit., p. 70) diz que

"a investigação de fatores determinantes da compreensão de textos no contexto escolar identifica, dentre outros fatores que crucialmente contribuem para o sucesso na leitura, $o$ conhecimento de vocabulário. O controle deliberado e consciente desse conhecimento em função de relações textuais é uma das marcas do leitor proficiente".

Com a fala da autora, fica claro o quanto é importante o trabalho com o léxico na sala de aula. É ele que poderá ser o responsável pelo enriquecimento lexical do aluno, permitindo que o mesmo possa ser capaz de ter maior número de esquemas para poder usar em situações determinadas.

As palavras marcadas pelo professor eram de conhecimento dos alunos. Apenas a palavra rabecão era desconhecida de um maior número. Quando o professor perguntou aos alunos o significado da palavra grisalha, percebemos dois pequenos deslizes.

Primeiro ao usar a palavra aí como marcadora da posição de grisalha. Da forma como ele colocou, parece que a palavra em questão pode ter mais de um significado se 
ocupar posições diferentes dentro de um texto. A palavra só tem um significado, e é aí que notamos o segundo deslize do professor.

Segundo aparece no dicionário Aurélio (1996), o termo grisalho se refere a cabelo preto ou castanho entremeado de fios brancos. Os alunos que disseram que o significado da palavra era branco não podem ser vistos como errados. Certamente o significado que deram à palavra é o que a mesma tem na cultura em que vivem. Vale a pena lembrar que, conforme Eco (1974) o significado de uma palavra ou expressão é dado conforme aquilo que é descrito pela cultura em que o falante vive.

O professor deveria ter mostrado para a turma que a palavra tem um significado dicionarizado e que aquele dado pelos alunos deve ser o que aprenderam em sua cultura. Deveria ter deixado claro para os alunos que o significado de um termo só pode ser uma unidade cultural. "Reconhecer a presença dessas unidades culturais (que são, portanto, os significados que o código faz corresponder ao sistema dos significantes) significa compreender a linguagem como fenômeno social" (Eco, op. cit.). Como não discutiu com os alunos a questão das unidades culturais e os significados dos termos, deixou transparecer um certo desconhecimento de Semântica.

Achamos que também deveria ter mostrado aos alunos que a palavra grisalha tem diferença com as demais exploradas por ele porque não apresenta significados diferentes em posições diferentes como a palavra acudiram que ele usou tão bem.

Continuando a aula...

Murilo: certo, alguém se propõe a ler o texto? Quem se propõe?

Um aluno então fez a leitura oral.

Murilo: bem, agora vamos fazer um trabalhinho de grupo. Cada grupo ficará com um parágrafo, e aí vocês vão reler novamente e discutir entre si, depois cada grupo pode escolher um relator, alguém para falar pelo grupo, como vocês entenderam e analisaram, depois vão apresentar da forma que quiserem, por exemplo, fazer dramatização, ou apenas expor o que se passou no trecho que vocês leram, vocês poderão fazer o comentário que quiserem, uma crítica, uma análise, tá? Cada grupo vai fazer isso, analisar melhor, discutir; depois apresentar pra gente, tá?

O professor distribuiu partes do texto (parágrafos que foram recortados por ele) para os alunos. Foram formados grupos de alunos com cinco integrantes mais ou menos cada. 
Observamos duas questões que achamos por bem comentar: primeiro, ele cortou o texto em partes e pediu para que cada grupo interpretasse a parte isolada do texto. Platão \& Fiorin (1997, p. 14) dizem que

"num texto, o significado de uma parte não é autônomo, mas depende das outras com que se relaciona. O resultado do significado de um texto não é o resultado de uma mera soma de suas partes, mas de uma certa combinação geradora de sentidos. Num texto, o sentido de cada parte é definido pela relação que mantém com as demais constituintes do todo".

O professor parece demonstrar que, para ele, o significado do texto é apenas um conjunto de parágrafos cujos significados devem ser extraídos um por um para assim chegar à mensagem do texto. Talvez a atividade de cortar o texto em parágrafos seja devido a uma formação estruturalista que deve ter tido. Parece que sua formação acadêmica no curso de Letras ensinou que a língua é fragmentada, formada a partir de partes isoladas umas das outras, e que toda manifestação lingüística é feita a partir dessas partes isoladas entre si e que não apresentam ligação aparente.

A segunda questão que percebemos é que os alunos já tinham feito a leitura silenciosa do texto no início da aula e a leitura oral.

Depois de feita a leitura dos parágrafos isolados, o professor chamou cada um dos grupos para ir à frente fazer a "interpretação" do que leram. Aqui aparecem apenas partes dessa atividade. À medida que os alunos liam os parágrafos, o professor fazia perguntas a eles com o intuito de gerar alguma discussão, o que acabava não acontecendo.

(4)

Murilo: aí, o que vocês acham então, voltando lá no texto. Não chamaram ou...

A3: eu acho que... as pessoas disse que queria ajudar, mas não fez nada por ele, uai!

Murilo: eles deram desculpa, né, é... e não levaram ele devido à farmácia ser no outro quarteirão e o velho ser muito pesado. Vocês acham que essa desculpa que eles deram é convincente?

A3: não! Não, porque a gente quando quer ajudar não importa se é pesado ou não, e eles eram muitas pessoas...

Murilo: e o velho tava morrendo, né?

A3: um cansava, o outro carregava pra ajudar...

Nesse instante houve uma grande confusão. Quase todos os alunos falaram de uma vez só. Não deu para distinguir o que um e outro falavam.

Murilo: mais alguma coisa? 
De novo a grande confusão

(6)

Murilo: atenção, pessoal! Vamos ouvir o outro grupo ali.

Uma aluna leu um parágrafo do texto.

(7)

A4: bom, né, é que ninguém mostrou interesse por saber onde ele morava e tudo mais. Ninguém quis ajudá-lo nem nada, sei lá, procurar algum parente...

Murilo: que mais que vocês querem dizer?

A5: ué, as pessoas viram ele passando mal, morrendo, né, e continuou...

A6: fingindo que não tava vendo nada... que não tava acontecendo nada...

A7: eu acho também que as pessoas se preocuparam enquanto ele tava com os pertences, todo mundo parava e pensava em ajudar, depois que os pertences sumiu, aí ninguém se importou mais.

Murilo: na opinião de vocês, por que as pessoas agiram assim? ter ajudado ele.

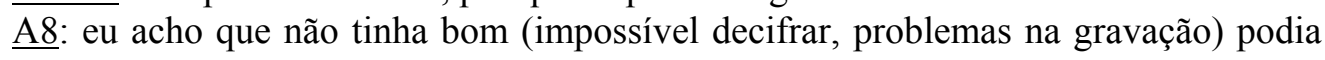

Outro aluno leu um parágrafo do texto.

Murilo: antes de vocês falarem, quero lembrar vocês como que o narrador onisciente, ele sabe, inclusive, até quantas horas o Dario, o Dario, né, levou pra morrer e quantas vezes foi pisoteado. Então, o narrador onisciente conhece completamente por dentro. Ele conhece tudo a respeito dos fatos, inclusive das personagens, é... que estão se, ...se envolvendo nos fatos, né.

A9: depois de, de, o pessoal ficar tentando inutilmente ajudar ele, inutilmente pelo, por eles não ter feito nada pra ajudar ele realmente, só ficar tentando, mas quando tinha uma mínima possibilidade, eles preferiam desistir em ajudar do que continuar a ajudar. Eles viram que ele tava morto, né, aí já deixou por conta do carro do IML pegar ele, né. Aí quando a polícia chegou já viu que não tinha nada que, o que realmente eles não queriam era nem ajudar, eles queriam era aproveitar. Deixou ele sem nada e aí só foi falar que ele tinha morrido e deixaram por conta do carro.

A10: eles viram que ele era um senhor apresentável e... então eles não queriam ajudar ele, só queriam, em, retirar os valor, e a hora que a polícia chegou, que a polícia foi ver se ele tinha alguma coisa, aí ele foi pisoteado.

A11: é... se cada um dos curiosos tivesse pensado em ajudar, na hora de levar ele para a farmácia, 04 curiosos teriam levado ele até a farmácia, teria pedido primeiros socorros e lá seguiria para o hospital, né. Se realmente eles tivessem preocupados com a saúde dele, é... que ele poderia tá morrendo, depois de 02 horas que aconteceu o primeiro...

A10: eles esperaram 02 horas é... prá... não ajudar. Viram a possibilidade, acharam difícil, não ajudaram pela dificuldade...

A11: eles só tavam interessados porque... tinha, né, alguma coisa de valor ali com ele, então a ajuda deles era o interesse próprio e não...

A12: quem chegou pra ajudar ele primeiro foi os mais esperto, né, que quando uma possibilidade de uma pessoa que... "ma o meno" não dá a pessoa em robá... 
Até aqui fica bem claro que o que os alunos estavam fazendo era uma reprodução daquilo que o autor já colocara no texto. $O$ professor pedia para que eles contassem o que leram.

Murilo: na opinião de vocês, o que leva o ser humano a agir dessa forma?

A11: ganância, ambição.

A13: acho que é... falta de educação, não é nem tanto ambição, é uma pessoa que faz só pensando em si.

Murilo: deixa a colega falar alguma coisa.

A14: as pessoas... que queriam ajudar eram...

Murilo: fingidas, né?

Aqui o professor cortou o raciocínio da aluna e não a deixou concluir sua idéia. Parece que ele temeu que a aluna não iria atender às suas expectativas, então interferiu dando a resposta que talvez não seria a dela.

Ele fez nova pergunta para a turma e começou de novo a mesma atividade de reprodução do que foi lido. $\mathrm{O}$ interessante foi notar que o professor orientava as atividades de forma que só ele fazia perguntas. Quando um aluno fazia algum questionamento, ele desviava a atenção da turma e seguia adiante sem responder àquela questão levantada.

A15: ele falou que a última boca repetiu "ele morreu, ele morreu". Queria saber o que que ele quis dizer com isso aí.

Murilo: é, vem cá!

Nesse instante soou o sinal e a aula terminou sem que o professor respondesse.

\section{Aula do Professor Rodolfo}

O professor Rodolfo utilizou uma metodologia um pouco diferente da do professor Murilo e diferente também do que se costuma usar em aulas de leitura. Ele entregou o texto aos alunos e pediu para que eles formassem grupos e saíssem para o pátio para que fizessem a leitura silenciosa individual e depois em grupo. Durante essa atividade houve alguma dispersão por parte dos alunos. Como o pátio da escola era muito grande, não havia como o professor visitar todos os grupos para acompanhar a discussão de cada um. 
O objetivo dele em fazer com que os alunos interpretassem o texto em grupos foi interessante, uma vez que ele teve o intuito de praticar a socialização entre eles. As atividades de leitura em grupo fazem parte das propostas teóricas de estudiosos como Vygotsky, porque valorizam a natureza social da aprendizagem (cf. Terzi, 1997). As atividades de leitura desenvolvidas em grupo ajudam o aluno a reiterar a relação autor-leitor.

O professor iniciou o trabalho com o texto discutindo algumas questões relacionadas à vida social. Quis então conseguir voluntários para a leitura oral do texto. A leitura foi feita espontaneamente pelos alunos. Quem quis ler, leu. A leitura oral chamava à atenção apenas dos alunos que queriam fazê-la. Os demais se perdiam em pequenas conversas paralelas.

Depois de feita a leitura pelos alunos, começou a discussão.

Rodolfo: muito bem, concluímos o trabalho de leitura, vamos dar início a uma discussão bem à vontade. Gostaria de saber primeiro de cada um, individualmente, o que é que você mudou na sua interpretação quando você saiu de seu grupo para passar para o grupo de três ou quatro, o que é que mudou? Você tava com um ponto de vista e depois quando passou para o grupo de três o que é que mudou na maneira de pensar? (...) Alguém notou alguma diferença? Todos concordaram com o que tava antes?

O professor insistiu muito nessa questão da mudança ou não de opinião a partir do momento em que houve a inserção dos alunos em grupos maiores. Também uma atividade interessante porque foi levada em consideração a atividade de discussão pelo grupo. Ele quis dar ênfase ao fato de que as opiniões podem mudar quando se discute algo em um grupo e que a opinião individual pode ser mudada pela persuasão de uma ou mais pessoas pertencentes a um grupo diferente.

A1: ah, foi um pouco diferente, mas a maioria foi igual. É a indignação de as pessoas não ajudar o homem.

Rodolfo: então quer dizer que não mudou muito?

A2: mudou porque alguém falou com outras palavras, só.

Rodolfo: ah, outras palavras? Quer dizer que cada um interpretou com outras palavras? Alguém mudou o ponto de vista, a maneira de interpretação?

Quando o professor começou a discutir a questão da interpretação de grupo ou individual, acabou se perdendo e falando sobre a influência da família e da escola na 
formação de cada um. Teria sido muito válida, cremos nós, a discussão se ele tivesse mostrado para os alunos que a formação que eles tiveram influencia na forma de ver as coisas e de entender o mundo, conseqüentemente, mudam as formas de se interpretar um texto.

Depois de algum tempo nessa atividade, o professor começou a fazer aos alunos as perguntas elaboradas por ele. A aula seguiu então sem maiores novidades. Algumas perguntas feitas pelo professor Rodolfo exigiam dos alunos a volta ao texto para que pudessem “copiar" as respostas das perguntas de interpretação. É uma atividade equivalente à atividade de decodificação (cf. Kleiman, 1995). As respostas eram lidas sem um envolvimento maior com a compreensão do texto e os alunos faziam então uso de uma pseudo-linguagem (cf. Terzi, 1997).

Quando o professor fez uma pergunta sobre o caráter do brasileiro, alguns alunos falaram sobre a desonestidade das pessoas e o interesse que têm em possuir o que é de direito dos outros. Ele então pediu a opinião dos alunos querendo saber se eles não achavam que a desonestidade dos brasileiros vem de sua formação, isto é, da formação histórica do povo brasileiro. Iniciou-se então uma longa fala do professor sobre a História do Brasil. Pôdese perceber que ele se perdeu um pouco em sua fala. Fez uma viagem à História do Brasil. Atividade interessante se tivesse sido feita a ligação entre o que ele falava e o que o texto tratava.

O professor Rodolfo ministrava, na época, conforme ele mesmo nos informou, aulas de História em outra escola. Talvez por isso quis fazer uso de seus conhecimentos na aula de Português. A interdisciplinaridade deve acontecer, mas o aluno deve perceber o porquê de tal ligação e o professor deve mostrar para ele o que está fazendo.

Enquanto falava a respeito da História do Brasil, uma pequena confusão começou na sala de aula. Alguns alunos falavam ao mesmo tempo e não foi possível entender muito bem o que o professor e os alunos falavam. O professor então se dirigiu a um casal de alunos que conversava distraidamente sobre outro assunto, provavelmente:

Rodolfo: vocês aqui, o que é que vocês acham? O que é que vocês estão pensando a respeito? Aqui, ó, vamos discutir aqui a respeito do texto, do contexto aqui, porque senão as conversas paralelas podem atrapalhar o colega. Pode começar.

Por um rápido instante a turma toda ficou sem ação, na expectativa, em silêncio. 
(4)

A3: Ai, professor, eu não gosto de ficar falando assim!

Rodolfo: mas é bom falar.

A3: ai, é que tá muito chato!

Rodolfo: atenção aí, gente! Vamos ouvir a colega. Como é que é?

A3: tá muito chato a humanidade se preocupando só com o bem material, igual vocês tavam falando. É muito difícil encontrar pessoas que sejam solidárias.

Depois de chamar a atenção desses alunos, Rodolfo voltou à turma e começou a falar sobre o problema da seca no Nordeste. Expôs então a questão da miséria vivida pelos nordestinos e o desinteresse do governo pelo assunto.

Em seguida passou a falar sobre a violência nas grandes cidades e o grande número de assaltos. Disse que a violência é o reflexo de que alguma coisa na sociedade está errada. Falou sobre a corrupção política e a provável ligação disso com a problemática da seca.

Todas as questões discutidas pelo professor Rodolfo eram pertinentes e tinham, de alguma forma, ligação com o texto que estava sendo discutido. A problemática com relação a seus comentários gira em torno do fato de ele não ter deixado claro para os alunos que sua fala tinha certa ligação com a história narrada por Trevisan.

A turma do professor Rodolfo era muito ativa e participativa. Qualquer assunto que ele iniciasse logo virava uma grande discussão. Realizar atividades com foco interativo naquela turma não parecia ser difícil.

Os alunos começaram a falar depois de um certo tempo apenas ouvindo o professor, que tomou conta da palavra em seguida.

A4: a culpa das coisas ruins é do governo, mas a culpa disso tudo é nossa.

A5: é um negócio também de cultura. A pessoa que estudou é o quê? É inocente. (Impossível decifrar. Problemas na gravação).

Rodolfo: ó! A menina falou um negócio aqui muito interessante. Ela falou assim: nós colocamos a culpa nos políticos. Teve muitos presidentes aí que não paga o voto que a gente votou. Mas nós também somos culpados pelo ruim que tá aí, por quê? Quantas vezes nós estávamos lá e o presidente da associação de bairros falou: fulano, vamos a uma reunião ali para discutir problemas de seu bairro. Quem aqui vai a essa reunião? Quem participa dos momentos culturais da cidade? Aqui ó! Nós colocamos ${ }^{1}$ nos jornais, revistas, eu nunca vi nenhum prefeito lá nas manifestações culturais, eu não vejo uma pessoa num lugar desses. Gente, e outra, o trabalho político também. A câmara dos vereadores, etc. Gente, se nós não nos colocarmos como construtores da História, colocarmos o dedo, como diriam os historiadores, no raio da

\footnotetext{
${ }^{1}$ O professor Rodolfo era, na época, presidente da Academia de Letras do município. Costumava mandar publicar em jornais e revistas locais avisos para a comunidade a respeito de feiras e semanas culturais realizadas por escolas, exposição de artes no museu local e eventos no museu histórico da cidade.
} 
História, nós também somos fabricadores de assaltantes porque nós somos co-autores desse crime concordam comigo?

A5: a gente colabora e nem percebe.

Rodolfo: a gente, nós estamos, ... a nossa não participação é a maior colaboração para elegermos os homens que nós temos no poder.

A6: o voto não é direito do cidadão? Então a gente tem direito a opinar e falar o que quer e o que não quer. Daí a gente não participa e não vê que vai ficando cada vez pior, porque tem que participar.

Rodolfo: tem que participar?

A6: tem que participar.

Foi impossível decifrar o que aconteceu em seguida. Os alunos falavam todos juntos e o professor não controlou isso. A gravação ficou tumultuada. Mas parte da aula em seguida foi tomada por uma discussão sobre política. Num dado momento surgiu um gancho para discussão a respeito da reforma agrária e mais uma vez formou-se um tumulto generalizado. Outra boa parte do tempo ficou nessa discussão.

Esse recorte de aula colocado anteriormente é um dos que mais apresentam acúmulo de informações por parte do professor. Poucas eram as vezes em que ele fazia ligação entre o que estava sendo falado e a história de Dario. Colocamos abaixo os assuntos discutidos pelo professor no recorte:

1. Culpa da sociedade pela colocação no poder de políticos ruins;

2. Falta de participação da comunidade na resolução dos problemas de seu bairro;

3. Falta de participação das pessoas e do prefeito em atividades culturais;

4. Participação das pessoas na co-autoria dos crimes de assalto.

Depois de trazer uma série de assuntos à tona, Rodolfo passou então a falar novamente sobre a História do Brasil, e agora também de Goiás. Toda essa discussão não tinha, aparentemente, relação nenhuma com a história de Dario. Os alunos falavam, mas a fala mais ouvida era a de Rodolfo. Parecia que ele partia do princípio de que o aluno nada sabia e cabia a ele definir o nível de ensino (cf. Terzi, 1997).

Momentos depois, Rodolfo voltou a falar sobre o texto. Voltou a fazer as perguntas e os alunos respondiam. Por alguns momentos eles ficaram mais calmos, mas logo em seguida começou o tumulto de novo. Ficou então difícil decifrar a gravação por causa das falas todas ao mesmo tempo. O professor não tomou atitude para acalmar os alunos. E assim a aula terminou.

\section{Considerações finais}


A conclusão a que se chega depois de observadas as duas aulas é que os professores em questão ainda não pareciam ter consciência de como desenvolver atividades de leitura em que a interação seja ponto principal. Os dois demonstraram uma forte ligação com a concepção de que, para ler e interpretar, o texto deve ser visto como um conjunto de palavras, sentenças, parágrafos, cujo significado deve ser, na maioria dos casos, dispensado.

A leitura pode ser uma das grandes responsáveis pela conscientização do aluno sobre seu papel no mundo em que vive. A leitura pode servir como um instrumento que liberta o homem da alienação e abre sua cabeça para enxergar as ideologias que estão por trás das coisas que o cercam. Ela pode fazer com que venha à tona o papel de agente sóciohistórico que o homem possui.

Não podemos perceber que estratégias de leitura os alunos possuíam. Como a condução da leitura e da interpretação foi muito decodificadora, não tivemos como avaliar a forma como os alunos usariam as previsões, as inferências, a relação entre informação visual e não visual.

Nenhum dos dois professores procurou ensinar aos alunos alguma forma de se ler um texto com a ativação de conhecimento de mundo ou inferência sobre pressupostos culturais.

Ambos - Murilo e Rodolfo - eram adeptos da atividade de leitura em voz alta com os alunos. Certamente tinham um objetivo para isso, uma vez que toda atividade desenvolvida em sala de aula tem um objetivo qualquer. Nenhum deles, felizmente, possuía o hábito de corrigir a leitura oral dos alunos. Apesar de os alunos cometerem falhas durante a leitura, os professores não os interrompiam.

Se o objetivo dos professores foi o de perceber se os alunos sabiam questões ligadas às regras ortográficas da língua, a leitura em voz alta deve tê-los ajudado a fazer isso. Se seu objetivo foi o de perceber se o aluno sabia fazer a entonação conforme a pontuação, também tiveram como verificar isso na leitura feita pelos alunos. Mas se tinham objetivo de perceber se os alunos entenderam aquilo que leram, a leitura em voz alta não teve fundamento algum.

O aluno que lê em voz alta costuma ter uma grande preocupação: como está sendo feita a pronúncia das palavras e a pontuação. Com isso, não tem como, além de perceber a leitura que faz, perceber o significado daquilo que lê. $O$ que ocorre então é uma mera decodificação dos sinais gráficos. O significado global do texto fica em segundo plano. 
Já a leitura silenciosa é diferente. $\mathrm{O}$ aluno tem a oportunidade de voltar e reler aquilo que para ele não ficou claro. Ele pode, assim, se envolver com o texto na busca de significados. Para isso, faz uso de seu ritmo próprio de leitura e de todas as regressões que se fizerem necessárias.

Os dados coletados mostraram que os professores não possuíam domínio das situações que aconteciam na sala de aula e não buscaram a prática da interação. Não levaram os alunos a serem participantes. Pode-se notar que grande parte da participação dos alunos não foi espontânea, eles não falavam porque queriam, mas porque eram indagados sobre alguma coisa.

O fato de as atividades desenvolvidas pelos dois professores pesquisados não serem muito significativas para os alunos acabou fazendo com que não houvesse incorporação do discurso e das ações do professor, não houve avanço em busca de independência por parte dos alunos. Isso não fez com que eles tivessem como se constituir como membros de um grupo de leitores, mas apenas como ouvintes e leitores passivos.

Poderiam ter sido propostas pelos professores Murilo e Rodolfo atividades que envolvessem o ensino de habilidades lingüísticas, ensino de capacidades específicas que desenvolvessem nos alunos a competência textual, a competência para lidar com textos. A boa atividade de leitura, além de desenvolver a criticidade dos alunos e interagi-los com o autor, deve levá-los a perceber as ligações que há entre as palavras e a captar as estruturas textuais, atitudes e intenções mostradas em um texto.

O trabalho com o léxico também é uma maneira de formar um bom leitor. Se o leitor for capaz de perceber as palavras-chaves componentes do texto, tem como manejar a melhor maneira de lidar com aquilo que é desconhecido. $\mathrm{O}$ ato de encontrar palavras-chaves também facilita ao aluno compreender o assunto do qual o texto trata e começar a formular idéias para que argumente a respeito do que lerá.

Outra forma de trabalho interessante, acreditamos, que poderia ter sido feita é o de leitura de outros textos que tratassem do mesmo assunto daquele levado para a aula. Isso poderia provocar condições para que os alunos fizessem comparações e então desenvolvessem a capacidade de analisar criticamente o uso da linguagem podendo atribuir assim intencionalidade ao autor.

Cremos que se o professor mostrar que o leitor deve se colocar como sujeito e passar a perceber o autor também como sujeito, a leitura se transforma num ato de interação, numa relação entre sujeitos que podem ter em comum um objeto. Numa leitura interativa, a 
que acreditamos ser eficiente, o leitor resignifica a linguagem construindo suas próprias idéias, opiniões, argumentos, que podem ser diferentes daqueles do autor.

Para finalizar, gostaríamos de dizer que a leitura e a interpretação de textos devem acontecer em um processo interacional. Para que isso ocorra com eficiência na escola, o professor deve procurar ser um mediador ajudando os alunos no descobrimento de quais estratégias devem usar para construir o sentido daquilo que está sendo lido. A pesquisa que fizemos não teve interesse em afirmar que a concepção interacional de leitura é a grande "salvadora". Porém, defendemos a idéia de que atividades de leitura e interpretação de textos, a partir da abordagem interacional, contribuem para que o aluno leitor leia enxergando o que não está explicitado, interagindo com o texto e construindo o seu sentido a partir de uma relação estabelecida entre texto, leitor e autor.

Levantamos a hipótese de que se aos alunos forem oferecidas condições de ler e interpretar textos apenas decodificando, eles apresentam tendência a se tornarem passivos e receptivos àquilo que são apresentados, deixando de perceber o texto como gerador de interação, cujo sentido é construído por leitor e autor, sócio-historicamente situados, tendo ele, o texto, por mediador.

\section{Referências Bibliográficas}

BAKHTIN, M. Marxismo e filosofia da linguagem. $8^{\text {a }}$ ed. São Paulo: Hucitec, 1997.

BRÁGGIO, S. L. B. Leitura e alfabetização: da concepção mecanicista à sociopsicolingüística. Porto Alegre: Artes Médicas, 1992.

CARVALHO, C. de. Para compreender Saussure. $7^{\mathrm{a}}$ ed. Petrópolis: Vozes, 1997.

ECO, U. As formas do conteúdo. São Paulo: Perspectiva/ Editora da USP, 1974.

FERREIRA, A. B. Novo dicionário da língua portuguesa. Rio de Janeiro: Editora Nova Fronteira, 1996.

FREIRE, P. A importância do ato de ler. São Paulo: Cortez, 1986

KLEIMAN, Â. Texto e leitor. $4^{\mathrm{a}}$ ed. Campinas: Pontes, 1995. . Leitura: ensino e pesquisa. $2^{\mathrm{a}}$ ed. - Campinas/SP: Pontes, 1996

MAC, M. I. de G. de \& WELTI, M. C. R. de. La organización textual: los conectores. Su aplicación en el aula. Buenos Aires: Editorial Plus Ultra, 1995. 
MOITA LOPES, L. P. Interdisciplinaridade e intertextualidade: leitura como prática social.

In: Anais do $3^{\circ}$ Seminário da Sociedade Internacional de Português e Língua Estrangeira. UFF, Niterói, 1996.

PLATÃO, F. \& FIORIN, J. L. Lições de texto: leitura e redação. São Paulo: Ática, 1997

TERZI, S. B. A construção da leitura. 2a ed., Campinas: Editora da UNICAMP, 1997. 
Anexo

\section{Uma Vela para Dario}

Dalton Trevisan

Dario vinha apressado, guarda-chuva no braço esquerdo e, assim que dobrou a esquina, diminuiu o passo até parar, encostando-se à parede de uma casa. Por ela escorregando, sentou-se na calçada, ainda úmida de chuva e descansou na pedra o cachimbo.

Dois ou três passantes rodearam-no e indagaram se não se sentia bem. Dario abriu a boca, moveu os lábios, não se ouviu resposta. O Senhor gordo, de branco, sugeriu que devia sofrer de ataque.

Ele reclinou-se mais um pouco, estendido na calçada, e o cachimbo tinha apagado. $\mathrm{O}$ rapaz de bigode pediu aos outros que se afastassem e o deixassem respirar. Abriu-lhe o paletó, o colarinho, a gravata e a cinta. Quando lhe retiraram os sapatos, Dario roncou feio e bolhas de espuma surgiram no canto da boca.

Cada pessoa que chegava erguia-se na ponta dos pés, embora não o pudesse ver. Os moradores da rua conversavam de uma porta à outra, as crianças foram despertadas e de pijama acudiram à janela. O Senhor gordo repetia que Dario sentara-se na calçada, soprando ainda a fumaça do cachimbo e encostando o guarda-chuva na parede. Mas não se via guarda-chuva ou cachimbo ao seu lado.

A velhinha de cabeça grisalha gritou que ele estava morrendo. Um grupo o arrastou para o táxi da esquina. Já no carro a metade do corpo, protestou o motorista: quem pagaria a corrida? Concordaram chamar a ambulância. Dario conduzido de volta e recostado à parede - não tinha os sapatos nem o alfinete de pérola na gravata.

Alguém informou da farmácia na outra rua. Não carregaram Dario além da esquina: a farmácia no fim do quarteirão e, além do mais, muito pesado. Foi largado na porta de uma peixaria. Enxame de moscas lhe cobriu o rosto, sem que fizesse um gesto para espantá-las.

Ocupado o café próximo pelas pessoas que vieram apreciar o incidente e, agora, comendo e bebendo, gozavam as delícias da noite. Dario ficou torto como o deixaram, no degrau da peixaria, sem o relógio de pulso.

Um terceiro sugeriu que lhe examinassem os papéis, retirados - com vários objetos - de seus bolsos e alinhados sobre a camisa branca. Ficaram sabendo seu nome, idade, sinal de nascença. O endereço na carteira era de outra cidade.

Registrou-se correria de mais de duzentos curiosos que, a essa hora, ocupavam toda a rua e as calçadas: era a polícia. O carro negro investiu na multidão. Várias pessoas tropeçaram no corpo de Dario, que foi pisoteado dezessete vezes.

O guarda aproximou-se do cadáver e não pôde identificá-lo - os bolsos vazios. Restava a aliança de ouro na mão esquerda, que ele próprio - quando vivo - só retirava umedecida com sabonete. Ficou decidido que o caso era com o rabecão.

A última boca repetiu - Ele morreu, ele morreu. A gente começou a se dispersar. Dario levara duas horas para morrer, ninguém acreditou que estivesse no fim. Agora, aos que podiam vê-lo tinha o ar de um defunto.

Um Senhor piedoso despi o paletó de Dario para lhe sustentar a cabeça. Cruzou as suas mãos no peito. Não pôde fechar os olhos nem a boca, onde a espuma tinha desaparecido. Apenas um homem morto e a multidão se espalhou, as mesas do café ficaram vazias. Na janela alguns moradores com almofadas para descansar os cotovelos.

Um menino de cor e descalço veio com uma vela, que acendeu ao lado do cadáver. Parecia morto há muitos anos, quase o retrato de um morto desbotado pela chuva.

Fecharam-se uma a uma as janelas e, três horas depois, lá estava Dario à espera do rabecão. A cabeça agora na pedra, sem o paletó, e o dedo sem a aliança. A vela tinha queimado mais da metade e apagou-se às primeiras gotas da chuva, que voltava a cair.

(Cemitério de Elefantes. $6^{\text {a }}$ ed., Rio de Janeiro, Record, 1980, pp. 40-43.) 